\begin{tabular}{lll} 
KULTURA & $\begin{array}{l}\text { POLSKA A KADEMIA NAUK } \\
\text { KOMITET SOCJOLOGII }\end{array}$ & ISSN 0023-5172 \\
I & $\begin{array}{l}\text { INSTYTUT ST DIÓW POLITYCZNYCH } \\
\text { SPOLECLENSTMO nr } 3 \quad \text { MIASTO I OKOLICE }\end{array}$ & \\
\hline
\end{tabular}

MAREK NOWAK

PIOTR FIRYCH

Uniwersytet im. Adama Mickiewicza w Poznaniu

\title{
MIĘDZYMIEŚCIE A UCZESTNICTWO W KULTURZE PRZYKŁADY Z POZNANIA I TRÓJMIASTA*
}

\begin{abstract}
WPROWADZENIE
Problem międzymieścia zaistniał w literaturze przedmiotu wraz z tendencjami, by czynić miasto bardziej spójnym. Pojęcie w wariancie niemieckojęzycznym - Zwischenstadt - do języka nauk o mieście wprowadził Thomas Sieverts (2003). Odpowiadająca mu tematyka, dość paradoksalnie, okazała się nośna w analizach miast amerykańskich czy w studiach urbanistów kanadyjskich,

Adres do korespondencji: marek.nowak@amu.edu.pl; piotr.firych@amu.edu.pl

* Poniższe rozważania zostały oparte na badaniach własnych z 2018 roku. Studium przypadku Górczyna zostało wówczas zrealizowane na zlecenie Wydziału Kultury Urzędu Miasta Poznania. Zawierało część ilościową i jakościową. W części ilościowej zrealizowano: wywiad kwestionariuszowy z mieszkańcami obszaru wyznaczonego granicami osiedli Górczyna i Fabianowa-Kotowa. Respondentów dobierano ad hoc podczas imprez kulturalnych, które odbywały się na ich terenie, oraz za pośrednictwem szkoły podstawowej i przedszkola pełniącego funkcję lokalnego ośrodka kulturalnego. Respondenci (zamieszkali na obszarze obydwu rad osiedli) w większości byli czynni zawodowo, średni rok urodzenia 1979 (nieco młodsi od całej próbki osób przebadanych w Poznaniu). Liczba nieco poniżej stu wywiadów z mieszkańcami analizowanego obszaru pozwala orzekać o pewnych elementach świadomościowych asocjacji związanych z uczestnictwem w kulturze, trudniej mówić o rozpowszechnieniu opinii wśród mieszkańców, co wymagałoby wykorzystania narzędzi gwarantujących probabilistyczny dobór próby. Część jakościowa obejmowała obserwacje, nieustrukturyzowane rozmowy z mieszkańcami oraz zogniskowane wywiady grupowe. Przywołujemy tu cytaty z poszczególnych wypowiedzi. Wyniki tych badań zostały zestawione $z$ ustaleniami zawartymi w istniejących opracowaniach dotyczących dzielnic Gdańska (Bachórz 2014 i in.; Bachórz 2017; Czarnecki 2012; Brosz, Załęcki 2017). Pozwoliło to na zastosowanie perspektywy porównawczej.
\end{abstract}


gdzie polityka planowania przestrzennego ma zdecydowanie inny status niż w Europie, a miasta w większym zakresie zmagały się (czy raczej zmagają się) ze zjawiskami suburbanizacji ${ }^{1}$.

Stwierdzenie, że współczesne doświadczenia środkowoeuropejskie mogą mieć więcej wspólnego $z$ historycznymi już perypetiami urbanizacji zza oce$a^{2}{ }^{2}$ niż na przykład $z$ tradycją porządkowania przestrzeni typową dla współczesnych „zwartych" miast europejskich, nie wydaje się szczególnie zaskakujące (zob. Ogrodnik 2015). Przesłanki takiej oceny znajdziemy już w założeniach tzw. szkoły chicagowskiej z końca XIX wieku (zob. Czekaj 2017; Rancew-Sikora, Michałowski, Dowgiłło 2016), według których przestrzeń różnicowały oddolne mechanizmy społecznej stratyfikacji, a podziały na „złe” i „dobre” dzielnice wyznaczały szanse szacunku i antyszacunku społecznego ${ }^{3}$. Miarą sukcesu ekonomicznego zaś było zamieszkiwanie „rozgęszczonych” dzielnic rezydencjalnych poza rogatkami miast. Model ten współcześnie ma istotne ograniczenia: po stronie przyczyn - konsekwencje kryzysu na rynku nieruchomości (słabsza dostępność kredytów hipotecznych), rosnące koszty energii, starzenie się społeczeństwa, zjawiska depopulacji; po stronie polityk publicznych — konsekwencje świadomie uruchamianych procesów rewitalizacji centrów miast (na co przeznacza się coraz więcej środków publicznych; por. założenia tzw. Karty Lipskiej UE) oraz dbałości o krajobraz i środowisko naturalne.

Niezależnie od diagnoz (i oczekiwań) ponowoczesne i posttransformacyjne miasto wytworzyło wiele przestrzeni „pomiędzy”, których status jest (był) niejasny i raczej kojarzy się z „korytarzem”, dostarczaniem czegoś czy obszarami poprzemysłowymi, mniej zaś na przykład z przestrzenią zamieszkania, a tym

${ }^{1}$ Suburbanizacja rozumiana jest tu jako rezultat kryzysu miasta (kryzysu centrum miasta), a nie atrybut jego rozwoju. Wiąże się zatem ze zjawiskami: „polegającymi na migracji użytkowników miasta (mieszkańców, podmiotów gospodarczych, instytucji sektora publicznego, ośrodków usługowych, handlowych, sektora badawczo-rozwojowego itd.) ze strefy centralnej na przedmieścia, często poza granice administracyjne ośrodka miejskiego. Jest to efekt decyzji lokalizacyjnych, które wynikają z pogarszania się warunków funkcjonowania w centrum miasta, wzrostu kosztów i braku możliwości rozwojowych w wyniku ograniczeń przestrzennych. W wielu opracowaniach łączy się to zjawisko z procesem rozgęszczania (dezurbanizacji) strefy centralnej miasta" (Heffner 2016, s. 79).

2 Odpowiedź, dlaczego urbanizacja środkowoeuropejska może być „bardziej amerykańska”, powstaje na styku dwóch pozostających wobec siebie w aksjologicznym napięciu zagadnień: specyfiki polityki przestrzennej modernistycznego miasta socjalistycznego (44 lata urbanizacji od końca drugiej wojny światowej) oraz dynamiki urynkowienia związanego z transformacją systemową początku lat dziewięćdziesiątych XX wieku (blisko 30 lat). Jest ona spowodowana zmianami w sferze normatywnych reguł gry (deregulacji), co ma wiele wspólnego z żywiołowością, chaotycznością miasta z przełomu wieków, często odpychającego formą kojarzoną z osiedlami domków czy blokami mieszkalnymi rozrzuconymi wśród pól, na obrzeżach terenów czynnych ekologicznie, w opozycji do struktur przestrzennych dysponujących gotową infrastrukturą komunikacyjną i zaplanowaną infrastrukturą edukacyjną czy usługową.

${ }^{3}$ Pozwalało to przenieść sedno dyskusji z zagadnienia relacyjności/funkcjonalności przestrzeni miasta na kwestie różnicowania i „wyodrębniania się” typowe dla miasta kapitalistycznego. 
bardziej — z uczestnictwem w kulturze. Jednocześnie miasta „rozlewając się” (czy rozgęszczając, jak częściej pisze się w literaturze przedmiotu) napotykają bariery ${ }^{4}$, borykają się z niedostatkami jakości życia miejskiego, a ich włodarze w coraz większym stopniu wykazują tendencję do konstruktywnego spoglądania w stronę obszarów dotychczas będących „kulisami” i „łącznikami”, a nie środkiem miejskiej sceny, zwłaszcza gdy napotykają opór, próbując zarządzać procesami metropolizacji. Międzymieście jawi się jako potencjał uspójniania przestrzeni miast i kompromis $\mathrm{w}$ dyskusji: suburbia, osiedla podmiejskie versus centrum. Na ten immanentnie zróżnicowany obraz nakładają się relacje społeczne i mechanizmy strukturyzowania społecznego - peryferie i wspomniane „łączniki” zasiedlane są i eksploatowane przez grupy mieszkańców o różnym statusie materialnym i o różnym zakresie potrzeb. Ze względu na swoje usytuowanie przestrzenne międzymieścia zachowują atuty użytkowania, których nie mają obszary poza rogatkami miast, są $\mathrm{w}$ większym stopniu przestrzeniami przynależnymi „do” niż oddzielonymi „od” (choćby przez zazwyczaj dobre skomunikowanie systemami publicznego transportu), mają potencjał miastotwórczy. Mają też potencjał katalizowania kultury. Pytanie: jakiej, dla kogo i w jakim stopniu samodzielnej jako obszar ekspresji obywateli?

\section{JAK ROZUMIEĆ MIĘDZYMIEŚCIE?}

Czym zatem jest międzymieście (zob. Young, Keil 2014, s. 1)? Otóż międzymieście nie jest ani „starym centrum miasta”, ani obszarem suburbiów (parafrazując pogląd Sievertsa: „że nie jest to ani miasto, ani teren zielony”), które częściej kojarzą się przestrzeniami podmiejskimi lub zgoła ze wsią, ale jest krajobrazem o zróżnicowanej intensywności zabudowy, z udziałem przestrzeni o znaczącym potencjale środowiskowym (z przyjętej perspektywy raczej wtórnym, na przykład zalewiska pozostałości po eksploatacji zasobów gliny, jak w Poznaniu), który odkrywamy zbliżając się do rogatek miast ${ }^{5}$. Jak podkreśla Thomas Sieverts (2003, s. 10):

„Specyficzne uwarunkowania dojrzałych społeczności industrialnych do pojęcia Zwischenstadt dodały z jednej strony niski poziom aktywności, z drugiej wolność - w zakresie lokowania funkcji. Gęstość profesji jest niska, a masowość zabudowy jest porównywalnie duża".

\footnotetext{
${ }^{4}$ Wątek ten interesująco opisują geografowie społeczni, na przykład poddając analizie bilans energii jako narzędzie pomiaru stopnia atrakcyjności i spoistości miasta (por. Kozaczko 2017).

${ }^{5}$ Warto dodać tutaj jeszcze jeden wątek związany z rozróżnieniem peryferyjności i międzymiejskości. Obydwa pojęcia różni pole znaczeniowe. Peryferyjnosć we współczesnym kontekście częściej oznacza przestrzeń, w której oddziaływanie pewnych aspektów „koncentryczności miasta” („zawierania się” w mieście) ulega stopniowalnemu osłabieniu, jest tak ze względu na narastanie barier przestrzennych (odległości i czasu potrzebnego na przemieszczenie się) i społecznych, co wytwarza pewien zakres immanentnych fenomenów zbiorowych (jak subkulturowość, gettoizacja, czy - po przeciwnej stronie kontinuum — dezintegracja społeczna).
} 
W rezultacie $z$ jednej strony obszary te kojarzą się z dominacją jednej funkcji, z drugiej strony denotują to, co „odzyskiwane” i rewitalizawane w rozumieniu bliskim tzw. postindustrial revitalization, co oznacza zmianę funkcji związaną z podupadaniem przemysłu na obrzeżach miast i zamianą wytwarzania na usługi bądź nowe obszary zamieszkania.

Współczesne pojęcie in-between city przybliża międzymieście do miasta, dekonstruuje jego pozacentralność i peryferyjność. Dzisiaj obszar ten stanowi rezerwuar podlegający strategiom dogęszczania i przedmiot zarówno prywatnych, jak i publicznych inwestycji. Taki status przestrzenno-kulturowy pociąga za sobą wiele kwestii, które da się ulokować w pojęciu miasta kompaktowego (zob. Ogrodnik 2015). Międzymiejskość to - w opozycji do oddalenia - forma powiązania, a nie wyodrębniania się. Infrastrukturalnie zaś - to istnienie newralgicznej infrastruktury, na przykład komunikacyjnej, a także energetycznej, wodociągowej itd., co gwarantuje funkcjonowanie organizmu miejskiego W powiązaniu $z$ obszarem metropolitalnym. W języku szkoły chicagowskiej to: obszar przejściowy (zone in transition; zob. Czekaj 2017; Rancew-Sikora, Michałowski, Dowgiłło 2016, s. 99).

Takie międzymieście coraz częściej jest przestrzenią nowo powstających zbiorowości i wspólnot lokalnych, których atrybutem jest przemieszanie starego z nowym i „odzyskanego" z "oryginalnym”, centralnego z peryferyjnym (w rozumieniu nie tylko fizycznego oddalenia, ale również relacji wobec „centrum"; zob. Zarycki 2010). Kultura miedzymieści jest kulturą powstałą na eklektycznym tożsamościowo gruncie, który nie jest ani wytwarzany ex nihilo, ani dziedziczony po przeszłych pokoleniach (co łączy się bardziej z doświadczeniami wiejskości niż miejskości, o czym przekonują studia historyczne). Podejmujemy tu zadanie uchwycenia specyfiki uczestnictwa w kulturze na wybranych obszarach międzymieści, gdyż dostrzegam w tej sferze jedną z palących kwestii dzisiejszych miast i źródło pytań o potrzeby kulturalne rosnącej grupy mieszkańców - pytań o to, jaką kulturę wytwarzają ich użytkownicy oraz jak ten wyłaniający się model uczestnictwa w kulturze ma się do kultury centrum miasta.

\section{JAK ROZUMIEĆ UCZESTNICTWO W KULTURZE MIĘDZYMIEŚCIA?}

Wyodrębniony status kultury międzymieści skłania do definiowania uczestnictwa w kulturze znacznie szerzej niż dotychczas ${ }^{6}$. Zawężony zakres zainteresowań badań nad kulturą dostrzegł między innymi Andrzej Tyszka (1971, s. 43; por. Kłoskowska 1964). Jego uwagi odnosiły się wówczas do sformalizowanych instytucji dystrybuujących dobra kultury wśród odbiorców. Współcze-

${ }^{6}$ Uwaga dotyczy obszaru polityki kulturalnej i uczestnictwa w kulturze. Definicje te odnosiły się przede wszystkim do zjawisk kultury instytucjonalnej, gdzie uczestnictwo w kulturze rozumiane było jako pójście do kina, teatru, opery czy muzeum. 
śnie hierarchiczność relacji instytucja-odbiorca podlega istotnym przemianom, co wiąże się z procesami demokratyzacji kultury oraz rozwojem kultury partycypacyjnej (zob. Kłosowski i in. 2011). Ogromne znaczenie dla poszukiwania nowej perspektywy widzenia uczestnictwa w kulturze mają różne czynniki warunkujące jego obecny kształt. Najważniejsze z nich to: festiwalizacja i wielozmysłowość współczesnej kultury, a także wzrost znaczenia nowych mediów i sposobów komunikacji (Szlendak, Olechnicki 2017) 7 . O tak zwanej „nowej widowni" pisze też Sławomir Czarnecki (2015), wskazując na wyzwania stojące przed organizatorami oferty kulturalnej. Nie jest przypadkiem, że szersze rozumienie pojęcia coraz częściej jest stosowane $\mathrm{w}$ środowisku badaczy nawiązujących do współczesnych studiów miejskich, z ich wielonurtowością i skoncentrowaniem na procesach endogenicznych, na co w Polsce zasadniczy wpływ miały chociażby projekty realizowane $\mathrm{w}$ ostatnich latach $\mathrm{w}$ Trójmieście ${ }^{8}$.

Uczestnictwo w kulturze pojmuję tu zatem w sposób bliski relacyjnej koncepcji kultury Marka Krajewskiego, który w pewnym zakresie nawiązuje do koncepcji „socjologii relacyjnej” Bruno Latoura (2010). W konsekwencji kultura „może być rozumiana jako sposób powiązania elementów konstruujących określoną zbiorowość" (Krajewski 2013, s. 32), a nieco bardziej precyzyjnie:

„[...] to, co jest efektem wiązania, choć zostaje określone poprzez to, co w ten sposób splecione, oddziałuje zwrotnie, dokonując przeobrażeń $\mathrm{w}$ relacjach konstytuujących każdy z heterogenicznych elementów tworzących tę specyficzną zbiorowość. Postrzeganie kultury jako efektu splatania tego, co społeczne, i czynnika, który ten proces kształtuje, pozwala dostrzec zarówno złożony, jak i dynamiczny charakter interesującego nas zjawiska" (Krajewski 2013, s. 33).

Marek Krajewski w późniejszym komentarzu do zainicjowanych przez badaczy z Trójmiasta debat zwraca uwagę na potrzebę znalezienia narzędzi, które pozwolą dostrzec, że polem kultury nie są wyłącznie instytucje i profesjonalna działalność artystyczna oraz że niekorzystanie z ich oferty nie oznacza braku uczestnictwa w kulturze. Dodaje, że „[...] można nie konsumować dóbr kultury dostarczanych przez jej przemysł i być nadal kulturalnym" (Krajewski 2017, s. 35). Dla poniższych rozważań istotne wydaje się to, by heterogeniczność międzymieścia potraktować jako element, aspekt potencjalności wytwarzania kultury - to, że uczestnictwo w kulturze zarówno wynika ze specyfiki obszaru zamieszkania (jak sugerują założenia szkoły chicagowskiej), jak i wytwarza określony model partycypacji, który (wyprzedzając nieco narrację) korzysta z bardziej wspólnotowej specyfiki budowania relacji społecznych, pozostają-

7 Tomasz Szlendak (2010) posługuje się terminem „iwentyzacja”.

${ }^{8}$ Do najważniejszych projektów należy tu zaliczyć między innymi „Poszerzanie pola kultury. Diagnoza potencjału sektora kultury w Gdańsku” i „Punkty styczne. Między kulturą a praktyką (nie)uczestnictwa" opracowane przez badaczy związanych z Instytutem Kultury Miejskiej i Uniwersytetem Gdańskim. Pokłosiem tych inicjatyw był szereg ogólnopolskich debat środowiskowych i publikacji, w tym konferencja „Pomorskie Poszerzanie Pola Kultury” z września 2017 roku. 
cych jednak wyraźnie w orbicie miejskich wzorów życia. Kultura jest tutaj zaledwie (bądź „aż”) jednym z elementów, wartym zdecydowanie większego docenienia, ponieważ czyni różnicę tam, gdzie osiągnięcie określonych celów publicznych jest trudniejsze, a w przypadku odleglejszych obszarów osadniczych $\mathrm{w}$ istocie mało możliwe ${ }^{9}$. Co ważne, potencjał kulturalny międzymieści jawi się jako immanentnie „niedomknięty” - choćby z tego powodu, że uczestniczenie w kulturze zawiera w sobie aspekt dynamiczny, otwarty i socjalizacyjny jednocześnie, co oznacza, że dotykamy procesu in statu nescendi, a nie jakiegoś status quo ante ${ }^{10}$.

Podobne postawienie sprawy w pewnym zakresie podważa założenia Krajewskiego albo czyni je mniej konsekwentnymi, gdy dowodzi on, że:

„[uczestnictwo w kulturze] [...] to oddziaływanie pewnego elementu (jednostki, grupy, ale też przedmiotu, organizmu żywego itp.) na sposób powiązania ze sobą części konstytuujących określoną zbiorowość" (Krajewski 2013, s. 50) ${ }^{11}$.

Nasze zastrzeżenie wynika $z$ konstruktywistycznego przekonania o potrzebie intencjonalnego oddziaływania na sferę kultury, nie dlatego że proces ten „wytwarza” mieszkańca-obywatela „bardziej wartościowego” z jakiegoś punktu widzenia (czy z punktu widzenia jakiegoś kanonu, który próbuje się uznawać a priori), ale dlatego, że zmienia miasto w sposób, który czyni je bardziej „samoistnym” w klasycznym rozumieniu samoistności (zob. Rybicki 1979).

Co wydaje się ważne - realizujący się zwrot w kierunku konstruktywistycznych polityk publicznych międzymieści może stanowić przejaw „dekolonizacji” w postrzeganiu rozwoju i praktycznego myślenia o zasadzie „pomocniczości”, tam gdzie może ona przynieść najlepsze rezultaty. Dotychczas częściej mówiono o budowaniu wspaniałych obszarów podmiejskich (glamour zones) w opozycji do miejskich centrów (zob. Young, Keil 2010, s. 87). Bądź (wracając do tytułowego zagadnienia uczestnictwa w kulturze) przeciwstawiano obrazy miejskich (w większości zinstytucjonalizowanych i utrwalonych) form uczestnictwa nieformalnym procesom wytwarzania zapotrzebowań kulturalnych i samowytwarzania odpowiedzi na te zapotrzebowania. Przy czym dla współczesnych polityk

${ }^{9}$ Staje się to wyraźne, gdy oceniamy skuteczność prób rozszerzania ofert miast na sąsiednie gminy (w ramach obszaru metropolitalnego) lub choćby niski stopień integracji systemów dostarczania zasobów, gdy na drodze stają granice administracyjne.

10 A szczegółowe pytania poza samą diagnozą (czy tak, czy nie) mogą obejmować bardziej szczegółowe kwestie: kto w kulturze uczestniczy i w którym miejscu antycypowanego procesu się znajdujemy (przy założeniu, że ewolucja uczestnictwa w kulturze ma charakter uniwersalny).

${ }^{11} \mathrm{~W}$ innym miejscu autor doprecyzowuje swoje stanowisko, posługując się organizacyjną metaforą: „uczestnictwo [w kulturze] jest formą obecności każdego możliwego do pomyślenia elementu $\mathrm{W}$ określonej zbiorowości, realizującą się poprzez powiązania z innymi częściami składowymi tworzącymi tę całość. W tym sensie: karoseria, silnik, koła, instalacje elektryczne uczestniczą w tej specyficznej zbiorowości, jaką jest samochód; z kolei nauczyciele, wychowawcy, sprzątający i dzieci, materialna infrastruktura, różnorodne instytucje uczestniczą w całości, którą określamy mianem szkoły; widzowie, wykonawcy, personel techniczny, urządzenia i pewna struktura architektoniczna są uczestnikami koncertu" (Krajewski 2013, s. 49). 
kulturalnych powoływanie do życia samodzielnych i „samozwrotnych” enklaw mogłoby być równie kłopotliwe jak sprowadzanie uczestnictwa w kulturze do konwencji odświętnych wizyt i „konsumpcji oferty” w piątkowe czy sobotnie wieczory, związanej z kulturą municypalnie koordynowaną i finansowaną z pieniędzy publicznych ${ }^{12}$.

\section{STUDIA PRZYPADKU}

\section{Dwa międzymieścia}

Gdańsk, podobnie jak sąsiadujące $z$ nim i wchodzące w skład aglomeracji trójmiejskiej Gdynia i Sopot, to obszar wyjątkowy na mapie Polski. Międzymieście jest bowiem od dawna wpisane w tamtejszą topografię, a w ostatnich dekadach tereny „pomiędzy” poddawane były nieustannym przemianom. Dlatego Wrzeszcz może stanowić $\mathrm{w}$ tych rozważaniach atrakcyjne poznawczo studium przypadku. Jest bowiem międzymiejskim fenomenem: dzielnica ta przeszła długą drogę wrastania w miasto, niegdyś peryferyjna - dziś w wielu aspektach pełni role typowe dla centrum. Jeszcze do niedawna zmagająca się $z$ wieloma problemami typowymi dla miejsc poprzemysłowych — dziśs stanowi jedno z tętniących życiem miejsc w Trójmieście. Obszar dzielnicy rozcina trasa 468 łącząca Sopot $z$ centrum Gdańska oraz równoległa do niej linia kolei metropolitalnej. Nie jest to jednak tylko położenie „na” trasie wylotowej. Międzymiejskiego charakteru Wrzeszcza doszukiwać się można w etymologicznych konotacjach jego niemieckiej nazwy, która przez lata wyewoluowała do tej z początku XIX wieku — „Langfuhr”, czyli „Długi Przejazd”, co brało się stąd, że ówczesna wieś ulokowana była przy drodze z Gdańska do Oliwy.

Innym przykładem historycznego międzymieścia jest obszar południowo-zachodniego Poznania, czyli terenów podległych dwóm samorządom osiedlowym: Radzie Osiedla Górczyn i Radzie Osiedla Fabianowo-Kotowo, tworzących historyczny poznański Górczyn. Obszar ten jest — podobnie jak Wrzeszcz „nanizany” na trasę wylotową (nr 196) w kierunku Wrocławia (lub Głogowa zgodnie z nazwą głównej ulicy przebiegającej przez dzielnicę: ulica Głogowska) i podzielony prostopadłymi torami kolejowymi wiodaccymi na południe oraz terenem poprzemysłowym, obecnie pokrytym rozlewiskami, popularnie zwanym Szachtami. Górczyn i obszary położone od niego na południowy zachód stopniowo były włączane $\mathrm{w}$ obręb administracyjny Poznania. Pierwotnie była to

12 Zazwyczaj pociąga to za sobą czasową intensyfikację indywidualnego transportu w centrum miasta i traktowanie obszarów o wyjątkowych walorach kulturalnych jako przestrzeni li tylko karnawalizacji i spędzania wolnego czasu. Inna z możliwych perspektyw mogłaby polegać na metaforze ekosystemu kultury. Dałoby to spojrzenie na międzymieście jako element żywego organizmu, w jego relacji do całości, co „organicystycznie” oddaje istotę naszego myślenia o międzymieściu (por. Holden 2015). 
wieś włączona do Poznania pod koniec XIX wieku (jest to zatem młodszy od Wrzeszcza obszar funkcjonalny).

Można więc doszukać się urbanistycznych paraleli między międzymieściami Gdańska i Poznania. Różnią się one jednak znacząco pod względem cech, które można wiązać z pojęciem miejskiej samoistności oraz pojęciem peryferyjności (cechy te nie mają charakteru zerojedynkowego, nie do końca również opisuje je nawiązanie do przestrzenności). Zestawienie obydwu obszarów pozwala na uchwycenie logiki urbanizacji, w której pojawienie się infrastruktury kulturalnej jest świadectwem urbanistycznego „dojrzewania” obszaru miasta. Właśnie pod tym względem Górczyn i Wrzeszcz są porównywalne w mniejszym stopniu, ale ich obserwacja może sugerować kierunki ewolucji przestrzenno-społeczno-kulturowej. Mogą również służyć jako atrakcyjne narzędzie eksperymentu myślowego dotyczącego logiki urbanizacji oraz - co dla nas ważniejsze - logiki wytwarzania potencjału kulturalnego dzielnic na obrzeżach miast.

\section{Wrzeszcz: „usamodzielniona peryferia”?}

Wrzeszcz to obecnie jedna z najważniejszych części Gdańska. Dzielnicę przecinają kluczowe szlaki komunikacyjne Trójmiasta (Szybka Kolei Miejska, Pomorska Kolej Metropolitarna), ponadto stanowi ona zaplecze handlowe-usługowe miasta. Wrzeszcz, podobnie jak poznański Górczyn, zanim stał się częścią terytorium poddanego ekspansji terytorialnej sąsiedniego miasta, długo był terenem wiejskim. Jego początki sięgają XIII wieku (najstarsza wzmianka pochodzi z 1263 roku; zob. Daniluk, Wasielewski 2012). Specyfiki tego miejsca nie da się uchwycić bez zagłębienia się w historię jego rozwoju. Przez długi czas istniały tam pojedyncze folwarki, cegielnie, gorzelnie, browary, piekarnie oraz młyny, kuźnice i fabryki popiołu wykorzystujące wody Strzyży, lokalnego potoku. Dzielnicą Gdańska stał się w roku 1814, co nastąpiło po ponownym przejęciu miasta przez Prusy. Do lat siedemdziesiątych XIX wieku miała ona charakter letniskowy, istniały tam dwory i podmiejskie posiadłości. Nie bez znaczenia dla charakteru dzielnicy są czasy stacjonowania wojska na jej terenie (adaptowanie obszaru pod zabudowę militarną) oraz działający do 2001 roku browar. Bogata historia naznaczyła to miejsce i w sposób zasadniczy wpływa do dziś na jego tożsamość.

Dzisiaj obszar ten dzieli się administracyjnie na Wrzeszcz Górny oraz Wrzeszcz Dolny. Jest dużą dzielnicą obejmującą teren kilkunastu dawnych wsi, majątków i osiedli; składa się z następujących jednostek terytorialnych: Górzyna, Strzyża, Kuźniczki, Nowe Szkoty, Srebrzysko, Święta Studzienka, Królewska Dolina. Poszczególne tereny i obiekty są adaptowane na dzisiejsze potrzeby mieszkańców, zmieniają swój charakter i funkcję. W przypadku Wrzeszcza międzymiejski charakter ma niewątpliwie znaczenie strategiczne dla jego rozwoju. Ważne jest to, że rozpoczął swoją drogę aneksyjną i późniejszą — integracyjną — znacznie wcześniej niż Górczyn, który dołączono do Poznania w roku 1897. 
Oprócz innych, oczywistych różnic oba międzymieścia dzieli więc także o 86 lat dłuższe funkcjonowanie w obrębie miasta.

\section{Kultura Wrzeszcza}

Należy uznać, że oferta kulturalna jest we Wrzeszczu wysoce rozwinięta. W dużej mierze stanowi o tym zaplecze instytucjonalne. We Wrzeszczu działają i animują życie mieszkańców między innymi oddział Gdańskiego Archipelagu Kultury („Winda”), Klub Żak z kinem i salą koncertową czy Miejski Teatr Miniatura. Zasadnicza aktywność mieszkańców skupia się także wokół centrów handlowych i zlokalizowanych w nich multipleksów, a nawet, jak w przypadku galerii Manhattan, biblioteki publicznej. Wrzeszcz to powszechnie znane skupisko środowisk twórczych - zarówno artystów, jak i organizacji pozarządowych. To także dzielnica tętniąca życiem studenckim, w której działają bary, restauracje i kawiarnie oraz między innymi: Klub Muzyczny Metro, Autsajder czy Klub Kwadratowa. Z Wrzeszczem sąsiadują ważne trójmiejskie uczelnie. Działają w nim szkoły artystyczne: Zespół Szkół Muzycznych w Gdańsku-Wrzeszczu oraz Ogólnokształcąca Szkoła Baletowa. Interesujące są na różne sposoby adaptowane obszary historyczne. Wrzeszcz wydaje się swoistym laboratorium tego typu procesów. W dzielnicy można zaobserwować ich zróżnicowane przejawy: od typowo developerskich inwestycji na terenie byłego browaru po otwarte na kulturę tereny powojskowe (Garnizon Kultury). Skalę bogactwa oferty kulturalnej Wrzeszcza dobrze obrazują liczby ${ }^{13}$. Zwiększaniu dostępności do oferty sprzyja fakt, że jest to miejsce dobrze skomunikowane infrastrukturalnie i informacyjnie. Istotnego elementu kultury Wrzeszcza należy dopatrywać się także w wymiarze tożsamościowym. Jest to miejsce, którego historią żyją mieszkańcy, dopatrując się w niej szczególnej wartości, nierzadko pisząc o tym $\mathrm{w}$ internecie ${ }^{14}$.

Percepcja i potencjały kultury gdańskiego międzymieścia

Charakterystykę Wrzeszcza opieramy tu na danych zawartych w opracowaniach opublikowanych w Trójmieście w ostatnich latach (Bachórz 2014 i in.; Bachórz 2017; Czarnecki 2012) oraz na obszernym raporcie dotyczącym oceny jakości życia przez mieszkańców poszczególnych dzielnic Gdańska. We wprowadzeniu do tej pracy autorzy piszą: „Jakość życia nie jest więc wielkością obiektywną, lecz agregatem wielu subiektywnych ocen odnoszących się do różnorodnych aspektów życia i walorów przestrzeni miejskiej. Wszystkie składniki

${ }^{13} \mathrm{~W}$ wyszukiwarce dostępnej na platformie internetowej Kultura Dostępna można znaleźć ponad dwieście wydarzeń kulturalnych w promieniu $5 \mathrm{~km}$ (dane z 5 lutego $2017 \mathrm{r}$.) (https://kulturadostepna.pl/wydarzenie/szukaj?locality $=\mathrm{Gda} \% \mathrm{C} 5 \% 84$ sk-Wrzeszcz).

${ }^{14}$ Zob. np. blog jednego z mieszkańców Wrzeszcza (www.jarekwasielewski.pl/zwrzeszcza/). 
określające jakość życia ulegają zmianom w czasie, a wraz z nimi zmieniają się też potrzeby i oczekiwania" (Brosz, Załęcki 2017, s. 6). Opracowanie to zawiera opis i interpretację poziomu jakości życia w nawiązaniu do subiektywnych potrzeb mieszkańców oraz ich potencjału kulturowego. Warto wyjść od konkluzji tej analizy, w której Wrzeszcz w ogólnym zestawieniu plasuje się w czołówce dzielnic o najwyższej średniej wskaźnika oceny jakości życia (Brosz, Załęcki 2017, s. 150). Oferta kulturalna — jedna z szesnastu wyodrębnionych kategorii - przez mieszkańców Wrzeszcza jest oceniana najlepiej na tle innych gdańskich dzielnic (średnia odpowiedzi dla pięciopunktowej skali: 4,22). Kulturę we Wrzeszczu można łączyć z infrastrukturą rekreacyjno-sportową, która również oceniana jest bardzo wysoko $(3,79)$. Natomiast o wiele gorzej oceniany jest stan środowiska naturalnego, co tym bardziej istotne w naszym porównaniu, że w przypadku poznańskiego Górczyna mówimy o ogromnym potencjale terenów zielonych. Na przykładzie Wrzeszcza można zatem pokazać, jakie są koszty utraty naturalnej przestrzeni na rzecz rozbudowy miasta. Mieszkańcy, co prawda, stosunkowo pozytywnie oceniają przestrzeń publiczną swojej dzielnicy, jednak ich ocena jest niższa niż w dzielnicach typowo peryferyjnych, jak Chełm, Jasień czy zbliżonych do Bałtyku: Żabianki-Jelitkowa i Przymorza Wielkiego.

W opracowaniu Brosza i Załęckiego kultura traktowana jest wąsko - jako oferta, do której mieszkańcy mogą mieć większy lub mniejszy dostęp i którą z różnych względów oceniają pozytywnie lub negatywnie. Autorzy parametryzują ocenę takich kwestii jak dostępność poszczególnych typów instytucji kultury i atrakcyjność ich oferty. Mieszkańcy Wrzeszcza Dolnego, Wrzeszcza Górnego i Strzyża wysoko oceniają funkcjonowanie większości instytucji. Na przykład dostępność teatrów i sal koncertowych $77,2 \%$ ankietowanych uznało za dobrą, bardzo dobrą bądź celującą, 70,5\% oceniło ich ofertę jako dobrą, bardzo dobrą bądź celującą. W przypadku bibliotek i czytelni było to: 77\% (pozytywna ocena dostępności), kin: 86\% (pozytywna ocena dostępności). Nieco gorzej mieszkańcy postrzegali dostępność dzielnicowych instytucji kultury: jedynie $43,7 \%$ respondentów oceniło ją pozytywnie, $17,4 \%$ nie miało na ten temat zdania. Jest to wyraźny sygnał potwierdzający wcześniej przedstawioną tezę, że kultura Wrzeszcza spełnia kryteria bliższe kulturze charakterystycznej dla centralnych obszarów miasta. Należy dodać, że na odbiór kultury we Wrzeszczu istotny wspływ ma zapewne dostępność informacji na temat imprez i wydarzeń kulturalnych, które odbywają się w dzielnicy: $55,2 \%$ badanych mieszkańców uznało ją za dobrą, bardzo dobrą bądź celującą.

W naszym odczuciu w tym obrazie kultury Wrzeszcza brakuje szerszej perspektywy. Analizie zostały poddane bowiem wyłącznie dostęp do oferty kulturalnej oraz jej powierzchowna ocena. Badanie jakości życia nie przynosi zatem odpowiedzi na pytanie o to, $w$ jakim stopniu zadowolenie $z$ oferty przekłada się na praktyki kulturalne. Zwracamy na to uwagę ze względu na pewien niedosyt wiedzy na temat uczestnictwa (bądź nieuczestnictwa) w kulturze mieszkańców 
Wrzeszcza i budowanych przez nich więzi ${ }^{15}$. Z pomocą przychodzą badania realizowane wokół pojęcia poszerzonego pola kultury, w tym bogaty $\mathrm{w}$ refleksje raport oparty na jakościowych badaniach uczestnictwa w kulturze w Gdańsku pt. Punkty styczne. Między kultura a praktyką (nie)uczestnictwa.

„Ważnym wnioskiem z przeprowadzonych badań — piszą autorzy (Bachórz i in. 2014, s. 104) - jest jednak wyeksponowanie pozornego charakteru tego, co określa się jako brak uczestnictwa w kulturze. Nie ulega wątpliwości, że kultura instytucjonalna rzeczywiście jest w doświadczeniu badanych marginalizowana, jednocześnie podejmują oni wiele praktyk alternatywnych w stosunku do korzystania $z$ oferty instytucji”.

Wartość poznawcza takiego ujęcia praktyk kulturalnych wydaje się nieoceniona. Zdaniem gdańskich badaczy pozwala ono ująć szereg napięć, takich jak: kultura odświętna i wpleciona w życie; kultura „na poważnie” i kultura dla relaksu i zabawy; kultura relacyjna i kultura zindywidualizowana; kultura powinnościowa i kultura wyboru; kultura „wydarzeniowo-instytucjonalna” i kultura „indywidualno-uwewnętrzniona” (Bachórz i in. 2014, s. 103). We wnioskach raportu autorzy konstatują:

„Przede wszystkim chodzi tu o różne formy zaangażowania pozainstytucjonalnego (indywidualnego, rodzinnego, środowiskowego), a także przesuwanie akcentów w kierunku aktywności czasu wolnego, wchodzących w zakres kultury szerokiej, pracy nad sobą lub aktywności rozrywkowych. Zauważalne jest zatem napięcie między pragnieniem docierania przez instytucje do uczestników życia kulturalnego a ich rosnącą autonomią i niechęcią do włączania się w aktywności oferowane w instytucjach" (Bachórz i in. 2014, s. 104).

Zaraz po tym dodają:

„W obliczu przemian w kulturze i w stylach życia warto szczególnie wyeksponować proces kształtowania się rozmaitych, zindywidualizowanych strategii «zarządzania» własnym uczestnictwem w kulturze. Są one pochodną dezinstytucjonalizacji życia kulturalnego i można je odczytywać jako kolejny przykład rozlewania się logiki samowystarczalności i prosumpcji w sferze kultury" (Bachórz $\mathrm{i}$ in. 2014, s. 104).

Jeśli zatem chcemy dostrzec szerszy potencjał tkwiący w kulturze Wrzeszcza i Górczyna, rozumianych jako obszar międzymieścia, to powinniśmy przyjąć powyższą perspektywę. Potencjały kulturalne tych międzymieści są znacznie bardziej wielowymiarowe i z pewnością nie ograniczają się do praktyk kultury instytucjonalnej.

${ }^{15}$ Analogiczne uwagi sformułował Marek Szczepański w raporcie dotyczącym życia mieszkańców Górnego Śląska (1991) i zaproponował podejście alternatywne względem wyżej przedstawionego. W procesie oceny przestrzeni miejsca zamieszkania wyodrębnił pięć podstawowych form ładu mających pośredni wpływ na jakość życia mieszkańców. Jednym z nich był ład społeczny, rozumiany jako sieć stosunków społecznych, więzi sąsiedzkich oraz identyfikacja z miejscem zamieszkania. 


\section{Górczyn: „niesamoistny łącznik”?}

Historia Górczyna to historia poszerzania zakresu wpływów miasta o obszary bezpośrednio sąsiadujące. Górczyn zresztą powstaje w powiązaniu z Poznaniem ${ }^{16}$. Data lokacji na prawie niemieckim ustalona jest przez historyków na 1253 rok, co oznacza, że wieś jest równolatkiem historycznej wsi Wrzeszcz. Pierwotnie prostopadły do trasy Głogowskiej układ Górczyna z czasem, wraz $z$ jego rozwojem, przekształcił się w układ równoległy, bez wyraźnego centrum dzielnicy, pomimo planów formułowanych jeszcze pod koniec XIX wieku przez niemieckich urbanistów. Współczesną strukturę urbanistyczną dzielnicy charakteryzuje brak spójności (co jest elementem typowym dla międzymieści). Badaczki Górczyna tak to przedstawiają:

„Przemiany z różnych okresów dziejowych nakładają się na siebie, a ponieważ nigdy nie były kontrolowane - tworzą wrażenie nieładu przestrzennego" (Gawęcka, Czaban 2002).

W latach siedemdziesiątych XX wieku pozostałości starej zabudowy zostały ostatecznie zburzone i na ich miejsce powstały bloki mieszkalne. Można powiedzieć, że zaburzenia struktury przestrzennej dzielnicy dokonały się pod wpływem newralgicznego statusu przelotowej ulicy Głogowskiej, która przyciągnęła większość usług, wyraźnie rozdzielając układ urbanistyczny, a współcześnie przekształciła się w czteropasmową arterię, która symbolicznie separuje od siebie części dzielnicy. Ponadto północna część dzielnicy wyraźnie utrzymuje usługowo-przemysłowy charakter, a południowa zyskała status dzielnicy niskiej zabudowy jednorodzinnej o dużym zagęszczeniu, bez wyraźnych przestrzeni wspólnych. Dzielnicę domykają tereny poprzemysłowe, po wydobyciu gliny, które po kilkudziesięciu latach stały się terenem zielonym poprzetykanym stawami o nieregularnym kształcie. Dalej na południowy zachód pojawia się bardziej rozproszona zabudowa i zaznacza się obecność usług, znajduje się tam między innymi kilka sklepów wielkopowierzchniowych i rozgęszczona zabudowa jednorodzinna.

Obszar objęty studium przypadku jest zatem niezwykle zróżnicowany społecznie: od terenów z niską zabudową kamieniczą, chciałoby się napisać małomiasteczkową, zamieszkanych przez osoby o niższym i średnim statusie materialnym (odziedziczonych po wsi Górczyn i początku urbanizacji z końca XIX wieku), tzw. blokowisk $z$ lat siedemdziesiątych XX wieku o zróżnicowanym składzie osobowym mieszkańców, z wyraźną dominacja osób starszych, poprzez osiedla domków jednorodzinnych z niewielkimi ogrodami, zamieszkanych przez polski wariant klasy średniej (po raz kolejny ze znacznym udziałem pokolenia wchodzącego $\mathrm{w}$ wiek emerytalny), aż po pozostałości zabu-

16 „Prawo lokowania Górczyna na prawie niemieckim nadał Przemysł II mieszczaninowi poznańskiemu Henrykowi z Trochu” (Wesołowski 2001). 
dowy wiejskiej wchłaniane w obręb miasta na przestrzeni ostatniego ćwierćwiecza.

\section{Kultura Górczyna}

W przypadku Górczyna na pierwszy plan wysuwa się brak infrastruktury instytucjonalnej pełniącej funkcje typowo kulturalne. Nie ma tu domu kultury ani filii biblioteki miejskiej. Mieszkańcy nie mają zatem do dyspozycji zbyt wielu wspólnych „punktów styku”, czyli miejsc, w których koncentrowałoby się życie osiedla. Nieliczne takie przestrzenie to Park Górczyński, Dworzec Górczyński (teren wokół dworca kolejowego o jednoznacznie zdefiniowanej funkcji), $\mathrm{CH}$ Panorama czy tzw. Szachty. Rozwój kultury na badanym terenie utrudnia także w sposób zasadniczy topografia miejsca. Jeśli definiuje się kulturę w sposób instytucjonalny, to łatwo wysnuć przekonanie, że w okolicy „nic się nie dzieje”. To jednak nieprawda. Z pewnością zakres oferty kulturalnej Górczyna nie dorównuje tej opisanej w przypadku Wrzeszcza, jednak naturalnie pojawia się ona w wielu kontekstach życia społeczności lokalnej. Dzieje się tak choćby tam, gdzie funkcje typowe dla instytucji kultury przejmują organizacje i miejsca o charakterze wspólnotowym, w tym w dużej mierze placówki oświatowe i kościoły. Ważną rolę odgrywają więc przestrzenie i infrastruktura wokół szkół (Szkoły Podstawowej nr 10 im. Arkadego Fiedlera oraz Szkoły Podstawowej nr 4 im. Armii Poznań, usytuowanej w sąsiedztwie głównej trasy wylotowej z Poznania), przedszkola, boiska sportowe oraz dwie parafie: Parafia pw. Świętego Krzyża oraz kościół rzymskokatolicki pw. Chrystusa Króla. Brak instytucji kultury uzupełniany jest swoistymi „interwencjami” w postaci doraźnych działań animacyjnych podejmowanych przez Radę Osiedla czy inne organy samorządowe. Należy podkreślić rolę, jaką w ostatnim czasie na terenach poza centrum odgrywa Estrada Poznańska, instytucja miejska zajmująca się organizacją imprez kulturalnych i zarządzająca przestrzeniami publicznymi w centrum miasta. W ramach rocznego budżetu instytucja ta realizuje na Górczynie wakacyjny program kulturalny. W 2017 roku w projekcie pt. „Górczyńskie Kulturobranie” zorganizowano między innymi koncerty i warsztaty dla dzieci.

W dzielnicy można zaobserwować wiele inicjatyw oddolnych, w których mieszkańcy naturalną koleją rzeczy muszą odgrywać aktywną rolę. Przykłady wydarzeń tego typu to: doroczny turniej piłkarski im. Macieja Zawiei, w który $z$ roku na rok angażuje się coraz większa liczba mieszkańców, lub cykliczne rajdy rowerowe mające na celu budowanie wspólnoty lokalnej i kolektywne odkrywanie uroków okolicy. Kulturę osiedlową wzmacnia także sektor prywatny, między innymi restauracja „109 za Rogiem” regularnie organizująca koncerty, prywatna Szkoła Muzyczna T.Burton czy sala zabaw dla dzieci „Siedmiogród”. Co istotne, znacznie efektywniej docierają one do lokalnego odbiorcy niż potencjalnie znacznie silniej oddziałujące na społeczność placówki oświatowe czy rady osiedli, co można stwierdzić odwiedzając odpowiednie konta na portalu 
Facebook prowadzone przez poszczególne podmioty. Na przykład grupa „109 za Rogiem" skupia wokół siebie 2236 obserwatorów, Szkoła Muzyczna T.Burton 1070, podczas gdy profile szkół czy przedszkoli rzadko przekraczają próg pięciuset „fanów” 17.

Tożsamości mieszkańców obszaru objętego przez studium przypadku należy szukać w multigeneracyjnym środowisku i rodzinie pojmowanej jako grupa pierwotna. Gdy respondentów mieszkających na badanym obszarze zapytaliśmy o zadowolenie $z$ oferty kulturalnej, okazało się ono stosunkowo niskie (około dziesięciu procent osób odpowiedziało twierdząco). Trzeba przy tym zaznaczyć, że potrzeby kulturalne w wizji rozmówców mają bardzo podstawowy charakter i kojarzą się jednoznacznie ze spędzaniem czasu wolnego, a nie z określonym „kulturalnym” stylem życia.

Gdy szukamy klucza interpretacyjnego dla obszaru, któremu można przypisać status międzymieścia, to na myśl przychodzi stopniowalne „oddalenie”. Przy czym nie tylko ma ono fizyczny (przestrzenny) charakter (w tym przypadku odległości od bezpośredniego sąsiedztwa: Łazarza — dzielnicy usytuowanej bliżej centrum miasta), ale również znajduje odzwierciedlenie w stanie świadomości mieszkańców (ponad połowa deklaratywnie określa poziom swojego zainteresowania kulturą jako średni lub niski). Ocena oferty kulturalnej w pewien sposób koresponduje zatem $z$ brakiem zainteresowania kulturą. Ilustracją specyfiki tego stanu rzeczy może być wypowiedź respondentki:

Tu jest pięknie z jednej strony, ale $z$ drugiej strony wtaśnie wszędzie jest daleko, tak. Więc moje dzieci jak ostatnio glosowaliśmy $w$ budżecie obywatelskim i była propozycja tam na Świerczewie koncerty tam, filmowe, nie pamiętam jak to się tam nazywało, to powiedziaty tak? Ale po co tam? A ja mówię, no bo, a chcecie, wolicie gdzieś tutaj blisko? Ale tutaj się nic nie dzieje. No to jest wtaśnie po to, żeby się coś zaczęto dziać. Więc też mi to dało do myślenia, że nawet moje małe dzieci tak sobie myśla, że tu się naprawdę nic nie dzieje. To tylko taki maty kij w mrowisko.

Według większości badanych mieszkańców uczestnictwo w kulturze nie pełni ważnej roli, postrzegają ją również w specyficzny sposób. Na podstawie formułowanych oczekiwań można sądzić, że konsumpcja kultury nie jest dla nich aktem indywidualnym, kojarzy się z doświadczeniem wspólnotowym: sąsiedzkim czy rodzinnym, przywodzącym na myśl stosunki społeczne typowe dla wsi, nie dla relacji wielkomiejskich. Respondenci deklarują, że najbardziej skłonni byliby uczestniczyć $\mathrm{w}$ festynach rodzinnych (średnia odpowiedzi na skali od 1 do 5: 4,10), koncercie plenerowym $(3,87)$. Trzeba przy tym zaznaczyć, że analiza składu społecznego zbiorowości badanych wskazuje dominację wyższego wykształcenia, preferencje te nie są zatem rezultatem niskiego kapitału edukacyjnego. Jednocześnie deklaracje „średniego” zainteresowania kulturą nie oznaczają, że ma ona dla mieszkańców obszaru zupełnie marginalne

17 Dane pozyskane z platformy Facebook 15 listopada 2017 r. 
znaczenie (choć zapewne jednoznacznie kojarzy się z czasem wolnym spędzanym $\mathrm{w}$ towarzystwie rodziny czy znajomych).

Stosunkowo podstawowemu zakresowi deklarowanych potrzeb towarzyszy rozpowszechnione przekonanie o braku oferty kulturalnej. Ponad połowa tych, którzy określają siebie jako aktywnych w sferze kultury, odpowiada przecząco na pytanie o zadowolenie $z$ oferty kulturalnej osiedla. Krytyczne opinie dotyczą jej różnorodności, podobnie krytycznie oceniany jest dostęp do informacji. Deklaracji typu: kultura jako dodatek, element czasu wolnego, coś mało ważnego, nie należy zatem traktować jako przejawu generalnego braku zainteresowania, raczej jest to skutek braku podobnych doświadczeń i oferty, która pozwoliłaby uczestniczyć w kulturze i nieco inaczej spojrzeć na jej konsumpcję i wytwarzanie.

Potencjały Górczyna - jak się nie ma, co się lubi...

Potencjał kulturalny można zilustrować danymi dotyczącymi sum deklarowanych na określone rodzaje aktywności kulturalnej. Najwyższą średnią wydatków respondenci zasugerowali dla festynu rodzinnego (23,78 zł), spektaklu teatralnego (21,63 zł) oraz dla imprezy tanecznej. Najwięcej deklaracji dotyczyło kina plenerowego i koncertu plenerowego $(19,91 \mathrm{zł})$ oraz koncertu w zamkniętej przestrzeni $(19,41$ złotych). Warto zwrócić uwagę na stosunkowo wysoką sumę zadeklarowaną za przedstawienie teatralne, przy nieco mniejszej liczbie osób wykazujących wolę, by za jego obejrzenie zapłacić.

Gdy badani odpowiadają, czego brakuje na ich osiedlu, istnieje niemal pełna zgoda, że na terenie Górczyna i Fabianowa-Kotowa brakuje kina plenerowego, kina stacjonarnego (najbardziej jednoznaczne deklaracje), biblioteki, miejsca spotkań czy domu kultury. Należy zwrócić uwagę na te ostatnie placówki aktywizacji i animowania kultury. Takiej oferty brakuje, a można zasugerować twierdzenie, że potrzeba uczestnictwa wytwarza się wraz z jej pobudzeniem, co wiąże się z praktykowaniem uczestnictwa.

Warto podkreślić, że częściej wskazywane rodzaje konsumowania kultury polegały na byciu widzem, a nie na jakiejś formie uczestnictwa. Świadczy to o podstawowym charakterze potrzeb mieszczących się w konwencjonalnym spędzaniu czasu wolnego. Preferowane są wydarzenia zbiorowe, które jednak muszą spełnić pewne istotne wymagania: $\mathrm{w}$ tym — być dostosowane do skali i zainteresowań widza zbiorowego, w większości zróżnicowanego pokoleniowo. Co ważne, braki (niekoniecznie wiążące się wprost z brakiem stałego miejsca przeznaczonego na uczestnictwo w kulturze) są tym bardziej dostrzegane, im dalej znajdziemy się od centrum miasta.

Wskazując na deficyty, członkowie rady osiedla sugerowali jednak, że na ich terenie odbyło się wiele cyklicznych wydarzeń (być może za mało rozpropagowanych), których cechą było łączenie ludycznego wymiaru z zaangażowaniem mieszkańców. Nawiązywali do imprez sportowych, które stały się lub mogły się 
stać pretekstem do spotkania społeczności, bądź do konkursów artystycznych, które pozwalały też na uczestnictwo w roli widza, dając przy tym możliwość utożsamienia się z artystą, ze względu na jego „lokalny” rodowód. Ideę łączenia konwencji i wykorzystywania istniejącego już potencjału ilustruje wypowiedź działacza samorządu:

[...] turniej śp. Macieja Zawiei, tu już jest zaczątek. Tu trzeba połaczyć z cześsią sportowa. Ja jestem tego zdania, że te Żuki [odniesienie od imprezy, która odbyła się na osiedlu kilka miesięcy wcześniej i zainteresowała lokalną publiczność] mogtyby wystapić na tę okoliczność [...] Tu potrzebny bytby dobry trener [...]. Żeby to nie było przypadkowe kopnięcie pitki i wokót tego budować różnego rodzaju imprezy można. Ja tutaj mówię o budowaniu tradycji generalnie rzecz biorac. W co warto wchodzić. [...] Gdzie jakaś tam infrastruktura jest taka to można po prostu tam coś organizować i budować dalej. Jeżeli się pojawiaja tego typu peretki, jak mówię jeden, drugi i już się zaczęło budować tradycję, myślac o tym parku...

Oto inna wypowiedź wskazująca na sferę działań związanych z krzewieniem kultury fizycznej.

[...] Szkoła Podstawowa nr 4 organizuje turnieje pitki nożnej i turniej siatkówki i koszykówki organizowane wtaśnie przez Szkotę Podstawowa nr 4 i przez Pana Gerarda Sobkowiaka, który no też zaczynat od niewielkiej ilości drużyn a też jest to już dość pokaźna impreza. No i teraz w tym roku nowość, biegi wtaśnie dla zainteresowanych. Też kolejny, kolejne takie spotkanie sportowe.

Inną sferą potencjału zmiany jest kierowanie oferty do konkretnych grup. Szczególnie wartościowymi beneficjentami działań kulturalnych okazują się osoby starsze (seniorzy) i dzieci, przy czym ma to być oczywiście pretekst do budowania lokalnego kapitału społecznego. I w jednym, i drugim przypadku (dzieci i seniorów) celowe wydaje się wyraźne powiązanie działalności z konkretnym miejscem. Takie role częściowo pełnią istniejące instytucje edukacyjne. Częściowo, bo ich aktywność limitowana jest zarówno problemami lokalowymi, jak i dostępnością działań aktywizujących. Jedna z uczestniczek spotkania fokusowego (z członkami rady osiedla) stwierdziła:

To jest wszystko zwiazane z finansami i tego nie ma. Ale to sa takie potrzeby które rzeczywiście by byty, bo ludzie by przychodzili tylko że to by musiało być systematyczne. To że my sobie robimy raz na jakiś czas koncert i jesteśmy niezadowoleni z frekwencji bo ludzie nie przyszli no bo akurat ich wtedy nie byto, to ich nie zainteresowato. Człowiek, który ma nie wiem, 55+, 65+, kiedy sobie ma tydzień czasu wolne i nie wie co $z$ soba zrobić to szuka pewnych rzeczy. Mamy uniwersytet III wieku, gdzie część ludzi jest zainteresowanych.

Warto zaznaczyć, że cześć problemów z lokalnym uczestnictwem w kulturze wynikała ze słabej komunikacji, a precyzyjniej braku narzędzi, które w sposób konwencjonalny pozwalałyby informować się o tym, co się dzieje i co jest planowane. Sugerowano, że współczesne media społecznościowe nie docierają do wszystkich mieszkańców osiedla, a informacja jest podstawą tego, by realizowane już przedsięwzięcia miały szansę spotkać się z zainteresowaniem i znaleźć swoją stałą publiczność. 


\section{WNIOSKI I OGÓLNE REKOMENDACJE}

Analiza obydwu przypadków pozwala dość wyraźnie dostrzec odrębne trajektorie rozwojowe obszarów miast o podobnym potencjale, które jednak wyraźnie różni poziom rozwoju. Widać to choćby w zestawieniu zakresu instytucjonalizacji sfery kultury oraz ocen mieszkańców zapytanych o poziom życia $z$ uwagi na ofertę kulturalną. Wskazuje to na istotny aspekt — związek między oceną dobrostanu mieszkańców a poziomem rozwoju kulturalnego - i inspiruje do nieco innego spojrzenia na znaczenie kultury w obszarach do niedawna wartościująco określanych jako „peryferyjne”.

Peryferyjność jako etykieta wydaje się nietrafna z wielu powodów, również funkcjonalnych, jeśli weźmie się pod uwagę współczesne tendencje rozwoju miast, a precyzyjniej — nacisk na realizację polityki przestrzennej. Inny powód dotyczy sensowności stojącego za nią podziału, gdy tendencja do „wyprowadzek” z miasta jest powszechna, a skład społeczny „migrantów” sugeruje ich przynależność do klasy średniej, traktowanej wszak jako fundament nowoczesnego społeczeństwa liberalnego.

Pojęcie międzymieścia ma wiele atutów, oferuje bowiem narzędzia konceptualizacji i operacjonalizacji zagadnień dotychczas niedocenionych badawczo. Obecnie się to zmienia, o czym świadczą przywołane badania. Użyteczne wydaje się też posługiwanie się relacyjną teorią kultury, która każe rezygnować z podziału na „kulturę wyższą" i „kulturę niższą”, kładąc nacisk na związek kultury i jej praktykowania z konkretną społecznością przestrzenną. Sprawia to, że poza obrazem instytucji kultury, który jest $z$ reguły podporządkowany napięciu na linii centrum-peryferie (instytucje centralne-instytucje peryferyjne czy brak instytucji), znajdujemy złożoną przestrzeń relacji między twórcami a odbiorcami (w wielu przypadkach granica między twórcą i odbiorcą ulega nawet zatarciu), co uruchamia dyskusję o statusie kultury w praktykach społeczności lokalnych. Wrzeszcz i Górczyn różni bardzo wiele, łączy je zaś rozbudowanie praktyk kulturalnych, które jednak występują w odmiennym środowisku instytucjonalnym. Górczyn oraz sąsiadujące Fabianowo-Kotowo są ilustracją procesu poszukiwania tożsamości i wypełniania przestrzeni pozbawionej centralnych (miejskich) instytucji kultury aktywnością opartą na oddolnych działaniach animowanych w szkołach, przedszkolach, parafiach, a także przez podmioty prywatne zorientowane na rynkowe samofinansowanie. Wrzeszcz zaś wydaje się „submiastem" w pewien sposób samowystarczalnym kulturalnie (samoistnym).

Pojawia się pytanie, $\mathrm{w}$ jakim stopniu $\mathrm{w}$ obydwu przypadkach można dostrzec dwa przeciwstawione punkty kontinuum procesu urbanizacji, na którym po jednej stronie (przypadek Górczyna) znajduje się struktura koncentryczna (według pojęcia Pawła Rybickiego; 1979), po drugiej „sąsiadująca”. Międzymieście ewoluowałoby, według tej logiki, od peryferyjności i zaplecza centrum do względnej samoistności. Co wydaje się ważne, w centrum znajdują się formy instytucjonalizacji kultury postrzeganie jako warunek konieczny, jednak nie 
wystarczający, by rozwój przebiegał w kierunku „samoistności”. Kluczem do zrozumienia kultury międzymieści wydaje się dostrzeżenie ich historycznego związku z wcześniejszymi fazami rozwoju, wiodącymi od wspólnot wiejskich (przypomnijmy, że początki Górczyna i Wrzeszcza to XIII wiek) poprzez silne związki z dominującym organizmem miejskim aż do zbiorowości o hybrydalnym charakterze, definiujących potrzeby kulturalne w specyficzny sposób. Tutaj przykład poznańskiego Górczyna może być instruktywny. Ważne są także odmienne dane pozyskane $\mathrm{w}$ badaniu poznańskim, w którym dostrzegliśmy odejście od pojmowania kultury jako czegoś, co w sposób jednoznaczny mogłoby określać poziom wykształcenia, obycia lub cech osobistych ludzi. Mieszkańcy udzielający odpowiedzi ankietowych i biorący udział w zogniskowanych wywiadach grupowych rozumieli kulturę jako wydzieloną część zorganizowanego życia społecznego, służącą raczej integracji niż edukacji. Wątki łączące życie codzienne z potrzebami kulturalnymi dają zatem podstawę do wysnucia wniosku, że kultura jest traktowana jako konsekwencja pewnego standardu życia, a nie jego źródło.

Kultura Górczyna to przede wszystkim kultura grup pierwotnych i społeczności sąsiedzkich. Wehikułem uczestnictwa w niej są miejsca spotkań, czasowe przestrzenie zgęszczeń interakcji ludzkich, które wytwarzają oryginalne działania. Istotne znaczenie dla tych społeczności mają festyny, potańcówki, które na określony czas integrują uczestników, stawiając ich w rolach zarówno odbiorców, jak i wytwórców wartości kulturalnych. Przestrzeń międzymieścia pozostawia również miejsce dla „wyspecjalizowanych” form działania kulturalnego, mają one jednak charakter bardziej zamknięty, często potrzebują jedynie podstawowych zasobów, jak choćby miejsca spotkań, gdy zaczynają przekraczać granice gospodarstwa domowego i sfery prywatnej. Charakter tych działań jest jednak każdorazowo podporządkowany zainteresowanym, a ludyczność (tak mocno akcentowana w badaniu Górczyna) jest raczej pretekstem do spotkania niż celem wydarzenia kulturalnego.

Czy zaproponowaną hipotezę da się obronić, powinny odpowiedzieć kolejne badania i kolejne działania w przestrzeniach międzymieści. Przedstawiona analiza pozwala stwierdzić, że (1) warto inwestować w kulturę, zaczynając od podstawowej diagnozy przestrzeni ważnych dla społeczności lokalnej jako miejsca spotkań, analizować mechanizm instytucjonalizacji działań kulturalnych, by usuwać bariery, jakie napotyka działanie oddolne (np. w sferze komunikowania i obiegu informacji). Dodajmy również, że (2) nie powinno się obyć bez zinstytucjonalizowanej kultury w przestrzeni międzymieścia, przy czym powstawanie instytucji publicznych powinno być traktowane jako naturalny, kolejny krok rozwoju miasta. Warto docenić również (3) znaczenie wartości środowiskowych dla społeczności, dla której również park bądź teren zielony może stać się przestrzenią spotkania i uczestnictwa w kulturze.

Na koniec wypada podważyć tradycyjny „koncentryczny” obraz kultury miasta i kulturę międzymieścia traktować jako wartość o ogromnym potencjale bu- 
dowania więzi sąsiedzkich i miasta, które znacznie lepiej odpowiada potrzebom mieszkańców.

\section{BIBLIOGRAFIA}

Bachórz Agata, Ciechorska-Kulesza Karolina, Czarnecki Sławomir, Grabowska Martyna, Knera Jakub, Michałowski Lesław, Stachura Krzysztof, Szultka Stanisław, Olbracht-Prądzyński Cezary, Zbieniarek Piotr, 2014, Punkty styczne. Między kultura a praktyka (nie)uczestnictwa, Instytut Kultury Miejskiej, Gdańsk (raport badawczy: http://www.nck.pl/badania/raporty/raport-punktystyczne-miedzy-kultura-a-praktyka-nie-uczestnictwa).

Bachórz Agata, 2017, Przemiany pomorskiego sektora kultury. 2012-2017, Gdańsk.

Brosz Maciej, Załęcki Jarosław, 2017, Jakość życia w Gdańsku i jej społeczno-przestrzenne uwarunkowania. Studium socjologiczne, Zakład Realizacji Badań Społecznych, Kawle Dolne.

Czarnecki Sławomir, 2015, Nowa widownia. O promocji w kulturze, Narodowe Centrum Kultury, Warszawa.

Czarnecki Sławomir i in., 2012, Poszerzanie pola kultury. Diagnoza potencjału sektora kultury w Gdańsku, Instytut Kultury Miejskiej, Gdańsk.

Czekaj Krzysztof, 2007, Socjologia szkoty chicagowskiej i jej recepcja w Polsce, Górnośląska Wyższa Szkoła Handlowa, Katowice.

Daniluk Jan, Wasielewski Jarosław, 2012, Dolny Wrzeszcz i Zaspa. Gdańskie dzielnice, Wydawnictwo Oskar, Gdańsk.

Gawęcka Agata, Czaban Alicja, 2002, Górczyn wizja urbanistyczna, „Kronika Miasta Poznania” 1.

Heffner Krystian, 2016, Proces suburbanizacji a polityka miejska w Polsce, w: Tadeusz Marszał (red.), Miasto - region - gospodarka w badaniach geograficznych. W stulecie urodzin Profesora Ludwika Straszewicza, Wydawnictwo Uniwersytetu Łódzkiego, Łódź.

Holden John, 2015, The Ecology of Culture. A Report commissioned by the Arts and Humanities Research Council's Cultural Value Project (https://ahrc.ukri.org/documents/project-reports-andreviews/the-ecology-of-culture).

Kłoskowska Antonina, 1964, Kultura masowa. Krytyka i obrona, Państwowe Wydawnictwo Naukowe, Warszawa.

Kłosowski Wojciech (red.), 2011, Kierunek kultura. Wstronę żywego uczestnictwa w kulturze, Mazowieckie Centrum Kultury i Sztuki, Warszawa.

Krajewski Marek, 2013, W kierunku relacyjnej koncepcji uczestnictwa w kulturze, „Kultura i Społeczeństwo", nr 1.

Krajewski Marek, 2017, „Ja poszerzam”, „Ty poszerzasz”... Poszerzanie pola kultury i wynikające stad nieporozumienia, w: Olbracht-Prondzyński Cezary, Zbieranek Piotr (red.), Pomorskie poszerzanie pola kultury. Dylematy — konteksty — działania, Gdańsk.

Kozaczko Mieczysław, 2017, Efektywność komunikacyjna miasta zwartego, „Rozwój Regionalny i Polityka Regionalna”, t. 37, s. 27-40.

Latour Bruno, 2010, Splatajac na nowo to, co społeczne. Wprowadzenie do teorii aktora-sieci, tłum. Aleksandra Derra, Krzysztof Abriszewski, Universitas, Kraków.

Ogrodnik Karolina, 2015, Idea miasta zwartego — definicja, główne założenia, aktualne praktyki, „Architecturae et Artibus", nr 4.

Olbracht-Prondzyński Cezary, Zbieranek Piotr (red.), 2017, Pomorskie poszerzanie pola kultury. Dylematy — konteksty — działania, Gdańsk.

Rancew-Sikora Dorota, Michałowski Lesław, Dowgiałło Bogna, 2016, Budowanie na granicach: Kultura nowych peryferii miejskich, jej potencjały i problem, „Studia Pedagogiczne”, t. LXIX. 
Potrzeby i potencjały, 2017, Potrzeby i potencjały kulturalne mieszkańców poznańskich osiedli, Regionalne Obserwatorium Kultury UAM, Poznań.

Rybicki Paweł, 1979, Struktura społecznego świata, Państwowe Wydawnictwo Naukowe, Warszawa.

Sieverts Thomas, 2003, Cities Without Cities: An Interpretation of the Zwischenstadt, Routledge, London-New York.

Szczepański Marek J., 1991, Wartości ekologiczne przestrzeni i miejsc. Wyniki badań empirycznych, w: Kazimiera Wódz (red.), Przestrzeń wielkiego miasta w perspektywie badań nad planowaniem $i$ żywiołowościa, Wydawnictwo Uniwersytetu Śląskiego, Katowice.

Szlendak Tomasz, 2010, Wielozmystowa kultura iwentu, „Kultura Współczesna”, nr 4.

Szlendak Tomasz, Olechnicki Krzysztof, 2017, Nowe praktyki kulturowe Polaków. Megaceremoniaty isubświaty, Wydawnictwo Naukowe PWN, Warszawa.

Tyszka Andrzej, 1971, Uczestnictwo w kulturze. O różnorodności stylów życia, Państwowe Wydawnictwo Naukowe, Warszawa.

Warkoczewska Magdalena, 2002, Między wsia a dzielnica Poznania. Górczyn i jego mieszkańcy w XIX i w pierwszej połowie XX wieku, „Kronika Miasta Poznania” 1.

Young Douglas, Keil Roger, 2010, Reconnecting the Disconnected: The Politics of Infrastructure in the In-between City, „Cities”, t. 27 (2), s. 87-95.

Young Douglas, Keil Roger, 2014, Location the Urban In-between: Tracking the Urban Politics of Infrostructure in Toronto, „International Journal of Urban and Rural Research”, t. 38 (5), s. 1589-1608.

Zarycki Tomasz, 2010, Peryferie. Nowe ujęcie zależności centro-peryferyjnych, Scholar, Warszawa.

\title{
"IN-BETWEEN CITY" AND PARTICIPATION IN CULTURE:
} EXAMPLES FROM POZNAŃ AND THE TRI-CITY

\author{
Marek Nowak, Piotr Firych \\ (Adam Mickiewicz University in Poznań)
}

\section{Summary}

This article is devoted to the spatial changes in the postmodern, post-transformation city, and particularly to areas that can be defined as the "in-between city" (German "Zwischenstadt"). This term refers to areas characterized by a change of function connected with the extensive spatial development of a city. The authors undertake to present studies of the case of the "in-between city" areas of two cities in Poland (Poznan and Gdańsk) and the various types of participation in culture that occur there. They call attention to the culture-forming and city-forming potential of "peripheral" areas, which are currently intensively urbanized but which not long ago were treated as industrial terrain or as areas for supplying resources (communications routes, energy infrastructure, etc.). The authors seek out the historical facts conditioning the evolution of the in-between city, as well as making use of the data collected during their study. They refer to the findings of the sociology of the city, the perspectives of culture studies, and the premises of a relational theory of culture.

\section{Key words / słowa kluczowe}

in-between city / Zwischenstadt / międzymieście, city / miasto, participation in culture / uczestnictwo w kulturze, local society / społeczność lokalna, Poznań, Gdańsk 